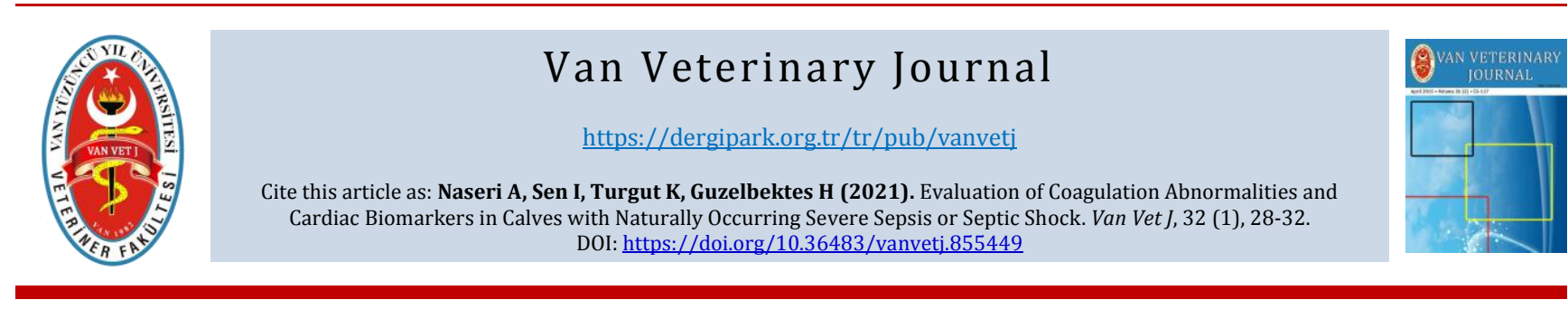

ISSN: 2149-3359

Original Article

e-ISSN: 2149-8644

\title{
Evaluation of Coagulation Abnormalities and Cardiac Biomarkers in Calves with Naturally Occurring Severe Sepsis or Septic Shock
}

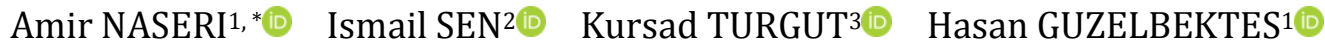 \\ ${ }^{1}$ Selcuk University, Faculty of Veterinary Medicine, Department of Internal Medicine, Konya, Turkey \\ ${ }^{2}$ Kyrgyz Turkish Manas University, Faculty of Veterinary Medicine, Department of Internal Medicine, Bishkek, Kyrgyzstan \\ ${ }^{3}$ Near East University, Faculty of Veterinary Medicine, Department of Internal Medicine, Nicosia, North Cyprus, Turkey \\ Received: 06.01.2021 \\ Accepted: 10.02.2021
}

ABSTRACT Coagulation abnormalities and myocardial injury frequently occur during sepsis. The aim of the present study was to evaluate the coagulation parameters and cardiac-specific biomarkers at set intervals in septic neonatal calves. Ten healthy calves and 20 septic calves were included in the study. For detecting coagulation parameters prothrombin time (PT), activated partial thromboplastin time (APTT), D-dimer, fibrinogen, antithrombin III (AT III), thrombocyte and, for cardiac biomarkers cardiac troponin (cTn) I, T, and creatine kinase-MB (CK-MB) were evaluated on admission, 24 and 72 hours later in septic calves and once in healthy calves. The results of coagulation parameters showed a significant elevation of PT and APTT times from the time of admission until the 72nd hour and a significant reduction of AT III and fibrinogen from the time of admission until the 72nd hour. Cardiac troponin T was high in the 72nd hour, and CK-MB was high in the time of admission, 24th and 72nd hours in septic calves compare to the healthy calves. There was a correlation between PT, APTT, fibrinogen with cardiac troponin T. In conclusion, cardiac damage can develop during the hypercoagulable state of disseminated intravascular coagulation (DIC), and maybe it is responsible for the elevation of cTnT and CK-MB and worse outcome in neonatal septic calves.

Keywords: Biomarker, Disseminated intravascular coagulation, Myocardium, Sepsis

öz

\section{Doğal Gelişen Şiddetli Sepsisli ve Septik Şoklu Buzağılarda Pıhtılaşma Bozuklukları ve Kardiyak Biyomarkırlarının Değerlendirilmesi}

Sepsis sırasında pıhtılașma anormallikleri ve miyokardiyal hasarı sıklıkla ortaya çıkmaktadır. Bu çalıșmanın amacı septik neonatal buzağılarda pıhtılaşma parametrelerini ve kardiyak spesifik biyobelirteçleri belirlenen aralıklarla değerlendirmekti. 20 adet sepsisli buzağı ve 10 adet sağlıklı buzağı dahil edildi. Pıhtılaşma parametreleri için prothrombin zamanı (PT), active edilmiş parsiyel tromboplastin zamanı (APTT), D-dimer, fibrinojen, antitrombin III (AT III), trombosit ve kardiyak biyobelirteçler için kardiyak troponin (cTn) I, T ve kreatin kinaz-MB (CK-MB) sepsisli buzağılarda tedavi öncesi, 24. ve 72. saatlerinde iki sefer ve sağlıklı buzağılarda tek sefer olarak değerlendirildi. Pıhtılaşma parametrelerinin sonuçları, PT ve APTT sürelerinde tedavi öncesinden 72. saate kadar önemli bir artış ve AT III ve fibrinojende tedavi öncesinden 72 . saate kadar önemli biraz azalma belirlendi. Sepsisli buzağılarda kardiyak troponin T ve CK-MB 72 saatte anlamlı olarak yükseldiği tespit edildi. PT, APTT, fibrinojen ile kardiyak troponin T arasında korelasyon olduğu belirlendi. Sonuç olarak, kardiyak hasar, yaygın damar için pıhtılaşmanın (YDP) hiperkoagülasyon aşamasında gelişebilir ve bu durum cTn T ve CK-MB yükselmesine ve prognozun kötü olmasına yol açabilmektedir.

Anahtar Kelimeler: Biyobelirteçler, Miyokard, Sepsis, Yaygın damar içi pıhtılaşma

\section{INTRODUCTION}

Sepsis is defined as infection-triggered systemic inflammatory response syndrome (SIRS) and causes high mortality in both human and animals (Martin et al. 2003; Naseri et al. 2019). Coagulation abnormalities frequently occur during sepsis (Anas et al. 2010). In cases with severe sepsis or septic shock, the hemostatic system dysregulation may lead to the clinical or sub-clinical disseminated intravascular coagulation (DIC) microthrombosis formation, global or regional hypoperfusion, multiple organ dysfunctions (MODS), and death (Hardaway et al. 2001). Studies in both companion and farm animals have clearly shown that coagulation abnormalities and DIC can occur during episodes of sepsis and septic shock and might be a significant risk factor for 
worse outcome (Irmak et al. 2006; Er and Ok 2015). Prothrombin time (PT), activated partial thromboplastin time (APTT), D-dimer, fibrinogen levels, antithrombin III (AT III) and thrombocyte (PLT) are useful in detecting DIC (Caldin et al. 2000).

Additionally, sepsis and septic shock can cause myocardial injury due to abnormalities in coronary perfusion and microcirculation (Mehta et al. 2004). Many factors such as inflammatory mediators, severe oxidative stress, calcium channel dysfunctions, nervous system dysfunction can lead to septic cardiomyopathy (Liu et al. 2017; Naseri et al. 2019; Ince et al. 2019). Studies in the endotoxemia in calves (Peek et al. 2008) and septic foals (Slack et al. 2005) showed that cardiac troponins (cTn) and creatine kinaseMB (CK-MB) are useful biomarkers for detecting cardiac injury during the inflammatory stage. However, there is a paucity of studies which demonstrate coagulation abnormalities and cardiac injury in septic neonatal calves. Therefore, the purpose of the present study was to evaluate the coagulation parameters, cardiac-specific biomarkers, and possible relationship between these parameters in septic neonatal calves.

\section{MATERIALS and METHODS}

The study protocol was approved by the domestic ethical committee at Selcuk University (No. 2015/04).

\section{Healthy Calves}

A total of 10 healthy Holstein calves from the Faculty Farm were included in the study. Calves were considered to be healthy according to the clinical examination and laboratory analysis findings (Constable et al. 2016).

\section{Septic Calves}

A total of 20 calves with a history of anorexia and diarrhea were selected. Calves included in the study met the criteria for severe sepsis or septic shock (Naseri et al. 2019). Heart rate (HR), body temperature, respiratory rate (RR) and degree of dehydration were evaluated. A standard treatment protocol for septic calves was applied (Naseri et al. 2019).

\section{Blood Sampling}

$8 \mathrm{~mL}$ blood were obtained by vena jugularis punctuation at time of admission, 24th, and 72nd hours for septic calves and once for healthy calves.

$5 \mathrm{ml}$ of collected blood transferred into the tubes without anticoagulant and centrifuged at $2000 \mathrm{~g}$ for 7 minute and extracted sera were stored at $-20{ }^{\circ} \mathrm{C}$. For evaluation of coagulation profile, the rest of $3 \mathrm{~mL}$ blood put into the sodium citrate containing tubes and after centrifuge the extracted plasma stored at $-20^{\circ} \mathrm{C}$.

\section{Coagulation Parameters and Cardiac Biomarkers}

Coagulation parameters (PT, APTT, D-dimer, AT III and fibrinogen) were measured by coagulometric method (SIEMENS, SYSMEX CA1500, Japan). Platelet counts were measured using a hematology autoanalyzer (MeletSchloesing Laboratories, CFE 279, France). Cardiac troponin $\mathrm{I}$ and $\mathrm{T}$ were measured by commercial bovine cardiac troponins ELISA kits (Mybiosource, USA). Also, CK$\mathrm{MB}$ was measured by serum biochemistry autoanalyserdevice (BT3000 plus, Italy).

\section{Statistical Analysis}

The distribution of the data was determined using the Kolmogorov-Smirnov test. For comparing the parametric values, ANOVA and Tukey tests were performed. Obtained results were calculated and presented as mean and standard deviation. For comparing the non-parametric values Mann-Whitney $U$ test was performed and presented as median and range. Statistical significance level was taken as $5 \%$. To seek correlations between coagulation parameters and cardiac biomarkers Spearman rank test and linear regression analyzes were used.

\section{RESULTS}

During the clinical examination, the calves were severely dehydrated and in lateral recumbent position. At the time of admission, all septic calves were hypotensive (systolic blood pressure (SBP) $<90 \mathrm{mmHg}$ or mean arterial pressure (MAP) $<65 \mathrm{mmHg}$ ). Two of 20 calves did not respond to fluid therapy and considered as septic shock. Nineteen calves $(19 / 20,95 \%)$ died during hospitalization period.

The results of coagulation parameters showed a significant elevation of PT and APTT and reduction of AT III and fibrinogen from the time of admission until 72nd hour. The changes of thrombocyte and D-dimer levels were not significant during the study period (Table 1).

Cardiac troponin T were higher in the septic calves at $72 \mathrm{~h}$ after admission compare to control calves. Also, the highest levels of CK-MB were established at the time of admission in septic calves in comparison to the healthy calves. The significant difference of CK-MB was observed at $72 \mathrm{~h}$ post admission. Although the levels of cTnI were higher in septic calves compare to healthy ones, this difference was not significant (Table 1). The Spearman rank analysis showed a positive correlation between cTnT, PT and APTT and negative correlation between cTnT and fibrinogen levels (Table 2). Linear regression analysis showed positive linear association between cTnT, PT and APTT and negative linear association between cTnT and fibrinogen (Figures 1, 2 and 3).

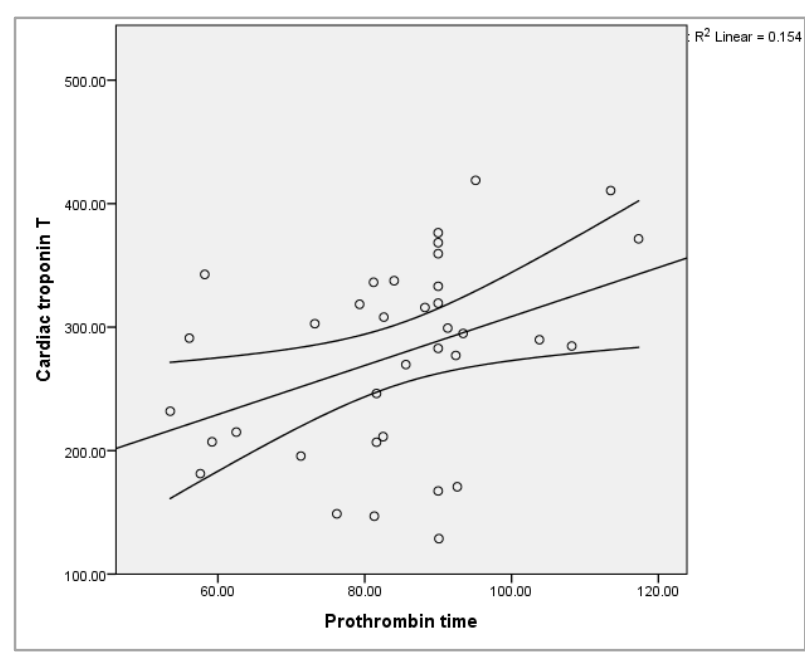

Figure 1. Regression analysis showed that there is positive linear correlation between cTnT and PT in septic calves $\left(\mathrm{R}^{2}=0.154, \mathrm{P}<0.01\right)$. 
Table 1. Comparison of coagulation variables and cardiac biomarkers between healthy and septic calves at set intervals. Data being expressed as mean $\pm \mathrm{SD}$ and median (range in parentheses).

\begin{tabular}{|c|c|c|c|c|}
\hline \multirow{2}{*}{ Parameter } & \multirow{2}{*}{$\begin{array}{c}\text { Healthy } \\
\text { Calves (n:10) }\end{array}$} & \multicolumn{3}{|c|}{ Septic calves (hour(s)) } \\
\hline & & 0 (n:20) & 24 (n:17) & 72 (n:12) \\
\hline PT (sec) & $68.53 \pm 10.42$ & $72.81 \pm 13.76$ & $84.23 \pm 13.24^{\mathrm{ab}}$ & $94.90 \pm 10.77 \mathrm{abc}$ \\
\hline APTT (sec) & $83.73 \pm 12.32$ & $86.73 \pm 13.94$ & $96.60 \pm 14.88$ & $119.30 \pm 20.19 \mathrm{abc}$ \\
\hline $\begin{array}{l}\text { Fibrinogen } \\
(\mathrm{mg} / \mathrm{mL})\end{array}$ & $280.38 \pm 90.17$ & $193.38 \pm 76.10^{a}$ & $134.77 \pm 60.81^{\mathrm{ab}}$ & $73.59 \pm 38.54^{\mathrm{abc}}$ \\
\hline D-dimer $(\mu \mathrm{g} / \mathrm{mL})$ & $0.15 \pm 0.02$ & $0.14 \pm 0.02$ & $0.16 \pm 0.01$ & $0.15 \pm 0.02$ \\
\hline AT III (\%) & $52.42 \pm 8.67$ & $48.64 \pm 15.52$ & $36.24 \pm 15.62^{\mathrm{ab}}$ & $27.06 \pm 16.4^{\mathrm{ab}}$ \\
\hline $\operatorname{PLT}\left(\mathrm{m} / \mathrm{mm}^{3}\right)$ & $390.40 \pm 195.13$ & $406.83 \pm 236.60$ & $406.75 \pm 274.79$ & $342.91 \pm 188.23$ \\
\hline cTnT (ng/ml) & $222.60 \pm 89.47$ & $262.86 \pm 65.64$ & $259.70 \pm 82.78$ & $307.98 \pm 79.6^{a}$ \\
\hline cTnI (ng/ml) & $\begin{array}{c}12.80 \\
(2.80-232.80)\end{array}$ & $\begin{array}{c}50.50 \\
(3.40-472.10)\end{array}$ & $\begin{array}{c}33.10 \\
(6.20-359.20)\end{array}$ & $\begin{array}{c}51.40 \\
(3.40-163.30)\end{array}$ \\
\hline $\begin{array}{l}\text { CK-MB } \\
(\mathrm{IU} / \mathrm{L})\end{array}$ & $\begin{array}{c}72.5 \\
(29.9-110.9)\end{array}$ & $\begin{array}{c}176.1^{a} \\
(12-2228)\end{array}$ & $\begin{array}{c}149.2^{a} \\
(44.6-838.4)\end{array}$ & $\begin{array}{c}92.00^{\mathrm{ab}} \\
(51.60-1513.30)\end{array}$ \\
\hline
\end{tabular}

a comparison between healthy calves $(\mathrm{P}<0.05)$, b comparison between time of admission $(\mathrm{P}<0.05)$, c comparison between $24^{\text {th }}$ and $72^{\text {nd }}$ hours $(\mathrm{P}<0.05)$, PT, prothrombin time; APTT, activated partial thromboplastin time; AT III, antithrombin III; cTn I, cardiac troponin I; cTnT, cardiac troponin T; CK-MB, creatine kinase-MB.

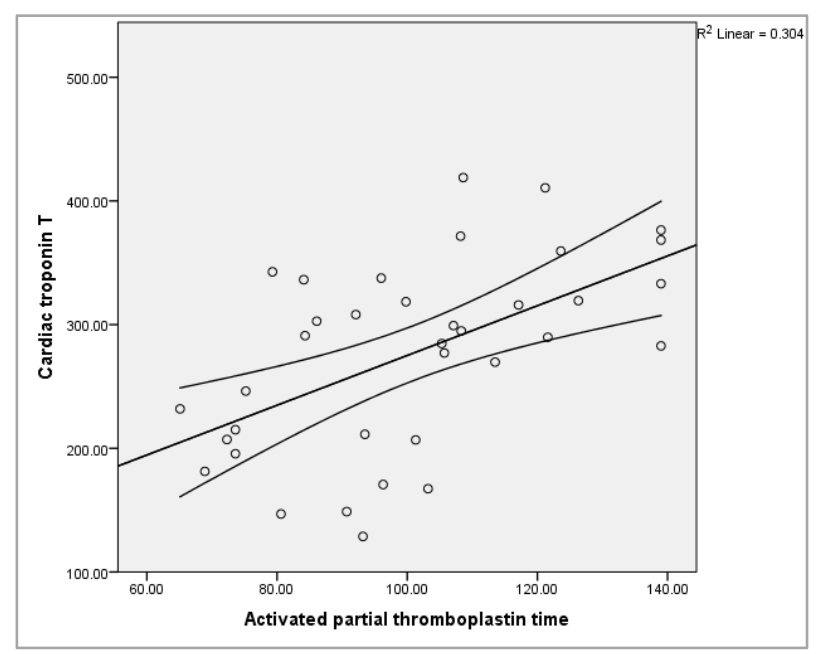

Figure 2. Regression analysis showed that there is positive linear correlation between cTnT and APTT in septic calves $\left(\mathrm{R}^{2}=0.304, \mathrm{P}<0.01\right)$.

Table 2. Spearman correlation coefficients of coagulation variables and cardiac biomarkers in 20 septic calves.

\begin{tabular}{lccc}
\hline Variable & CTnT & CTnI & CK-MB \\
\hline PT & $0.381^{* *}$ & 0.292 & -0.163 \\
APTT & $0.447^{* *}$ & 0.118 & -0.030 \\
Fibrinogen & $-0.375^{*}$ & -0.076 & 0.063 \\
D-dimer & -0.029 & 0.113 & -0.065 \\
AT III & -0.059 & -0.171 & -0.080 \\
PLT & 0.226 & 0.169 & -0.126 \\
\hline
\end{tabular}

${ }^{*} \mathrm{P}<0.05,{ }^{* *} \mathrm{P}<0.01, \mathrm{PT}$, prothrombin time; APTT, activated partial thromboplastin time; AT III, antithrombin III; cTn I, cardiac troponin I; cTnT, cardiac troponin T; CK-MB, creatine kinase-MB.

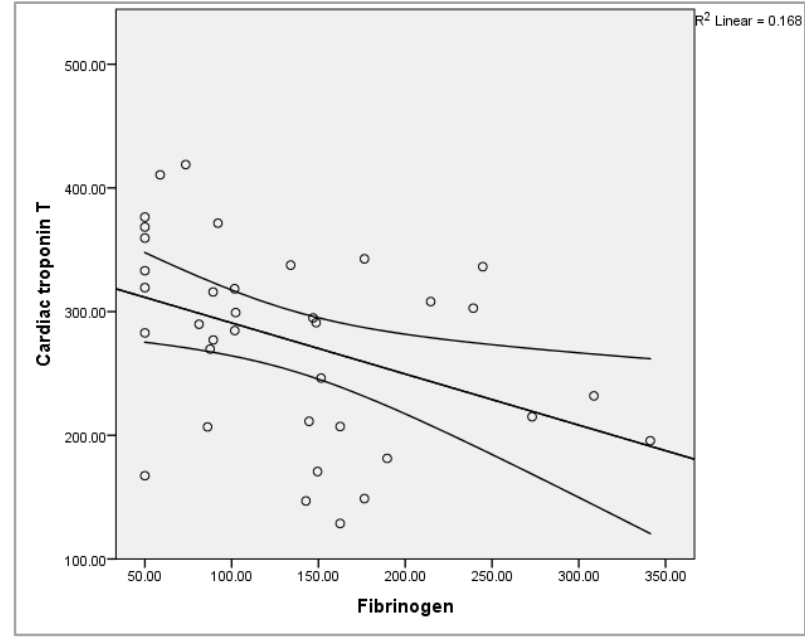

Figure 3. Regression analysis showed that there is negative linear correlation between cTnT and fibrinogen in septic calves $\left(\mathrm{R}^{2}=0.168, \mathrm{P}<0.05\right)$.

\section{DISCUSSION and CONCLUSION}

Traditionally, it is suggested that evaluating PLT count, PT, APTT, and AT III, fibrinogen, fibrin degradation products, D-dimer levels, and schistocytes are useful laboratory tests for detecting DIC (Turgut 2000). However, Wada and his colleagues stated that hemostatic system dysfunction and imbalance between hypercoagulation and hyperfibrinolysis state led to the DIC in patients with sepsis. In septic patients hypercoagulation state is remarkable and can lead to the MODS (Wada et al. 2014). Accordingly, the septic calves can be classified as hypercoagulation predominance type DIC. In sepsis initiation of coagulation is tightly dependent to the epithelium activation. This hypercoagulation predominance type of DIC can lead to microthrombi formation, ischemia, and MODS (Kenney et al. 2010; Taylor 2015). 
In the results of the present study, the coagulation parameters showed a significant elevation of PT and APTT, and a significant reduction of AT III and fibrinogen. Different studies in diarrhetic calves demonstrated that because of the presence of sepsis or septic shock in neonatal calves, the most common findings were the prolongation of PT and APTT (Irmak et al. 2006; Gökçe et al. 2006; Sobiech et al. 2013). It is accepted that at least $25 \%$ prolongation in PT or APTT is necessary for making the decision of consumption of coagulation factors for hypercoagulation (de Laforcade et al. 2003). For this reason, when we evaluate the results of PT and APTT in our study, the prolongation of PT and APTT was meaningful at $72 \mathrm{~h}$ post admission. This shows that excessive consumption of clotting factors at $72 \mathrm{~h}$ of admission have been developed due to the severity of the disease. AT III deals with hemostatic disorders. Previous studies in animals also showed that AT III activity in inflammatory diseases has reduced and may be indicative of changes in the hypercoagulability state (Barton et al. 1998; de Laforcade et al. 2003). Levi (2013) determined that hypofibrinogenemia is one of the findings of coagulation abnormalities in human DIC. Hypofibrinogenemia is an uncommon manifestation of DIC in large animals (Morris 1996) and, may suggest the hypercoagulation and concomitant liver dysfunction in septic calves. All these results show us that hypercoagulation is remarkable and dominant (hypercoagulation predominance type of DIC) and organ failure was the main symptom observed in the calves with sepsis (Kenney et al. 2010; Taylor 2015). However, there was no significant change in the levels of thrombocyte and D-dimer in the present study period. These results showed that hyperfibrinolysis was not remarkable (no hyperfibrinolysis predominance type of DIC) in the calves with sepsis.

Echocardiographic studies in septic calves showed that severe cardiovascular compromise had developed as a result of sepsis and septic shock in calves (Mehta et al. 2004; Erturk et al. 2018; Naseri et al. 2018; Naseri et al. 2019). There is no data available with regards to cardiac biomarkers in naturally occurring neonatal calves' septicemia. In the present study, cTnT was high in 72nd hour, and CK-MB were high in time of admission, 24th and 72 nd hours in septic calves compare to the healthy calves. Cardiac troponins are regulatory proteins of the actin filaments of the myocardium (Ammann et al. 2004). Cardiac troponin I and $\mathrm{T}$ are released in consequence of myocardial cell damage (Wong and White 2005). Previous studies in ruminants demonstrated that variety of diseases such as monensinintoxication (Varga et al. 2009), traumatic reticulopericarditis (Gunes et al. 2008), ventricular tachycardia (Naseri et al. 2017), and endotoxemia (Peek et al. 2008) can lead to cardiac injury and the elevation of cardiac troponins, especially cTnI. Aydogdu and his colleagues informed that the blood serum concentrations of cTnT and CK-MB (not cTnI) were significantly higher in neonatal calves with respiratory distress syndrome compare to healthy calves (Aydogdu et al. 2016). Thus, the elevation of cTnTand CK-MB in the calves with sepsis may indicate that acute cardiac injury, because of abnormalities in coronary perfusion and microcirculation, is a part of MODS observed in calves with sepsis, due to hypercoagulation predominance type of DIC. This could also be supported with the correlation and linear association between PT, APTT and fibrinogen levels with cTnT.
The findings of the present study showed that cardiac damage can develop during the hypercoagulable state of DIC because of prolongation of APTT and PT, reduction in AT III activity and decrease in fibrinogen concentration, and is also responsible for the elevation of cTnT and CK$\mathrm{MB}$ and poor outcome in neonatal septic calves.

\section{CONFLICTS of INTEREST}

The authors report no conflicts of interest.

\section{ACKNOWLEDGMENT}

This study was supported by the Scientific and Technological Research Council of Turkey (Project number: 1130218). Presented, in part in abstract form, at the IV International Academic Research Congress (INES) Congress, Antalya, Turkey in 2018.

\section{AUTHOR CONTRIBUTIONS}

Idea / Concept: AN, IS

Design: IS, KT

Supervision / Consultancy: IS, KT, HG

Data Collection and / or Processing: AN

Analysis and / or Interpretation: AN, KT

Literature Review: AN

Writing the Article: AN, IS, KT, HG

Critical Review: AN, IS, KT, HG

\section{REFERENCES}

Ammann P, Pfisterer M, Fehr T, Rickli H (2004). Raised cardiac troponins. Br Med J, 328, 1028-1029.

Anas AA, Wiersinga WJ, de Vos AF, van der Poll T (2010). Recent insights into the pathogenesis of bacterial sepsis. Neth J Med, 68, $147 \mathrm{e} 52$

Aydogdu U, Yildiz R, Guzelbektes H, Coskun A, Sen I (2016). Cardiac biomarkers in premature calves with respiratory distress syndrome. Acta Vet Hung, 64, 38-46.

Barton MH, Morris DD, Norton N, Prasse KW (1998). Hemostatic and fibrinolytic indices in neonatal foals with presumed septicemia. $J$ Vet Intern Med, 12, 26-35.

Caldin M, Furlanello T, Lubas $G$ (2000). Validation of an immunoturbidimetric D-dimer assay in canine citrated plasma. Vet Clin Pathol, 29, 51-54.

Constable PD, Hinchcliff KW, Done SH, Grünberg W (2016). Veterinary Medicine: A Textbook of the Diseases of Cattle, Sheep, Goats and Horses, 11th edition, St. Louis, MO.

de Laforcade AM, Freeman LM, Shaw SP, Brooks MB, Rozanski EA, Rush JE (2003). Hemostatic changes in dogs with naturally occurring sepsis. J Vet Intern Med, 17, 674-679.

Er C, Ok M (2015). Levels of cardiac biomarkers and coagulation profiles in dogs with parvoviral enteritis. Kafkas Univ Vet Fak Derg, 21, 383-388.

Erturk A, Durgut MK, Naseri A, Ok M (2018). Echocardiography, Ultrasonography and Laboratory Findings of Left Ventricular Systolic Dysfunction and Right-Sided Congestive Heart Failure in A Neonatal Calf. CDVS, 1, 145-149.

Gökçe G, Gökçe Hİ, Erdoğan HM, Güneş V, Citil M (2006). Investigation of the coagulation profile in calves with neonatal diarrhoea. Turk J Vet Anim Sci, 30, 223-227.

Gunes V, Atalan G, Citil M, Erdogan HM (2008). Use of cardiac troponin kits for the qualitative determination of myocardial cell damage due to traumatic reticuloperitonitis in cattle. Vet Rec, 162, 514-517.

Hardaway RM, Williams CH, Vasquez Y (2001). Disseminated intravascular coagulation in sepsis. Semin Thromb Hemost, 27, 577e83.

Ince ME, Turgut K, Akar A, Naseri A, Sen I, Süleymanoglu H, Ertan M, Sagmanligil V (2019). Prognostic importance of tissue Doppler imaging of systolic and diastolic functions in dogs with severe sepsis and septic shock. Acta Vet Hung, 67, 517-528.

Irmak K, Sen I, Cöl R, Birdane FM, Güzelbektes H, Civelek T, Yulmaz A Turgut K (2006). The evaluation of coagulation profiles in calves with suspected septic shock. Vet Res Commun, 30, 497-503. 
Kenney EM, Rozanski EA, Rush JE, deLaforcade-Buress AM, Berg JR, Silverstein DC, Montealegre CD, Jutkowitz LA, Adamantos S, Ovbey DH, Boysen SR, Shaw SP (2010). Association between outcome and organ system dysfunction in dogs with sepsis: 114 cases (2003-2007). J Am Vet Med Assoc, 236, 83-87.

Levi M (2013). Pathogenesis and management of peripartum coagulopathic calamities (disseminated intravascular coagulation and amniotic fluid metabolism). Thromb Res, 131, S32-S34.

Liu YC, Yu MM, Shou ST, Chai YF (2017). Sepsis-induced cardiomyopathy: mechanisms and treatments. Front Immunol, 8, 1021.

Martin GS, Mannino DM, Eaton S, Moss M (2003). The epidemiology of sepsis in the United States from 1979 through 2000. N Engl J Med, 348, $1546 \mathrm{e} 54$.

Mehta NJ, Khan IA, Gupta V, Jani K, Gowda RM, Smith PR (2004). Cardiac troponin I predicts myocardial dysfunction and adverse outcome in septic shock. Int J Cardiol, 95, 13-17.

Morris DD (1996). Alterations in clotting profile. In: Large Animal Internal Medicine. Smith BP. Ed. Mosby, Missuri, USA.

Naseri A, Ider M, Ok M (2017). Sustained polymorphic ventricular tachycardia in a calf. Eurasian J Vet Sci, 33, 130-132.

Naseri A, Sen I, Turgut K, Guzelbektes H, Constable PD (2019). Echocardiographic assessment of left ventricular systolic function in neonatal calves with naturally occurring sepsis or septic shock due to diarrhea. Res Vet Sci, 126, 103-112.
Naseri A, Turgut K, Sen I, Ider M, Akar A (2018). Myocardial depression in a calf with septic shock. Vet Rec Case Rep, 6, e000513.

Peek SF, Apple FS, Murakami MA, Crump PM, Semrad SD (2008). Cardiac isoenzymes in healthy Holstein calves and calves with experimentally induced endotoxemia. Can J Vet Res, 72, 356.

Slack JA, McGuirk SM, Erb HN, Lien L, Coombs D, Semrad SD, Riseberg A, Marques F, Darien B, Fallon L, Burns P (2005). Biochemical markers of cardiac injury in normal, surviving septic, or nonsurviving septic neonatal foals. J Vet Intern Med, 19, 577-580.

Sobiech P, Rękawek W, Ali M, Targoński R, Żarczyńska K, Snarska A, Stopyra A (2013). Changes in blood acid-base balance parameters and coagulation profile during diarrhea in calves. Pol J Vet, 16, 543-549.

Taylor S (2015). A review of equine sepsis. Equine Vet Educ, 27, 99-109.

Turgut K (2000).Veteriner Klinik Laboratuvar Teşhis. 2. baskı. Konya, Bahçıvanlar Basım San AŞ.

Varga A, Schober KE, Holloman CH, Stromberg PC, Lakritz J, Rings DM (2009). Correlation of serum cardiac troponin I and myocardial damage in cattle with monensin toxicosis. J Vet Intern Med, 23, 11081116.

Wada H, Matsumoto T, Yamashita Y (2014). Diagnosis and treatment of disseminated intravascular coagulation (DIC) according to four DIC guidelines. J Intensive Care Med, 2, 15.

Wong CK, White HD (2005). Implications of the new definition of myocardial infarction. Postgrad Med J, 81, 552-5. 